\title{
Moderate Communitarianism ANd The Idea of Political Morality in African Democratic Practice
}

\author{
- Hasskei M. Majeed -
}

\begin{abstract}
This paper explores how moderate communitarianism could bring about a greater sense of political morality in the practice of democracy in contemporary Africa. Moderate communitarianism is a thesis traceable to Kwame Gyekye, the Akan philosopher. This thesis is a moderation of the influence of the community in the Akan, an African social structure. In ensuring good political morality in the Akan, and therefore the African community, Gyekye proposes moral revolution over the enforcement of the law. I perform two main tasks in this article: (i) I reinforce the view that in a democratic framework (such as the framework within which many African states now find themselves), moderate communitarianism offers lessons on political morality, and (ii) I challenge the notion that moral revolution has greater prospects for bringing about political morality than law enforcement.
\end{abstract}

Keywords: moderate communitarianism, political morality, personhood, human rights, corruption. Published online: 30 September 2018

\section{Introduction}

It is quite tempting to think of Africa, especially sub-Saharan Africa, as a homogeneous unit, given the apparent similarity of the cultural beliefs and practices of her peoples. The unintended consequence of this thinking is the tendency for one to suppose that African cultures or their thinkers share the same philosophical ideas. But there are significant differences of opinion among African thinkers that are as worthy of note since they have enriched philosophical debates - especially, in academic philosophy - on the continent of Africa. In recent discussions on an important subject like communitarianism, such diversity and quality of philosophical opinion have been exhibited by a number of authors. Indeed, right from Placide Tempels, ${ }^{1}$ to John Mbiti, ${ }^{2}$ Ifeanyi Menkiti, ${ }^{3}$ Kwame Gyekye,${ }^{4}$

\footnotetext{
Hasskei M. Majeed

Department of Philosophy \& Classics

P.O. Box LG 211

University of Ghana

Legon, Ghana

e-mail:mmajeed@ug.edu.gh

${ }^{1}$ Tempels (1959).

${ }^{2}$ Mbiti (1989).

${ }^{3}$ Menkiti (1984).

${ }^{4}$ Gyekye (1997).
} 
Bernard Matolino, ${ }^{5}$ J.O. Famakinwa ${ }^{6}$ and more recently Martin Ajei, ${ }^{7}$ this concept has been debated upon both skilfully and in depth.

The philosophical interest in communitarianism has largely been sustained by the nuances or intellectual complexities involved in the determination of the basis for an atomic constituent of the community (that is, the person), the relation between the person and the community, prioritisation of rights and responsibilities between the two, and the potential which the African contextual responses to these questions have to influence moral and political decisions or lives in contemporary Africa. But the political direction of most African countries, at least as often expressed in political circles, is toward multi-party democracy. In this paper, I discuss moderate communitarianism in particular, with the objective of exploring its relevance to democratic practice in contemporary Africa. This is done, nonetheless, from an Akan perspective and, thus, within a Ghanaian political framework. ${ }^{8}$ In this respect, I take Gyekye's moderate communitarian thesis to be the proper presentation of communitarianism in Akan culture, and will seek to derive a political morality from it (as it is applicable to multi-party democracy in Africa). I seek to improve upon Gyekye's attempt at such a derivation.

The concept of political morality is then explored from the Akan cultural perspective, with the understanding of political morality being morality connected with the behaviour of political leaders and appointees in the performance of their duties. The originality of this paper lies partly in its ability to identify and utilise such values from the communitarian Akan culture that enhance political morality, those that have the tendency to impinge on political morality, and how the Akan culture makes the resolution of difficulties brought about by the latter 'values' possible.

Finally, lessons from moderate communitarianism are offered as a basis for the development of good political morality (or a higher sense of it) in a multi-party democratic country. The democratic dispensation in Ghana, and possibly in many African countries as well, is characterised by a myriad of inadequacies and tensions. For instance, there is a growing influence of the demands of individualism due, in part, to urbanisation and Western education; yet the people are supposed to be culturally communitarian. I explore how the resulting tension might be negotiated at the level of political morality - especially, at the state level - using the problems of human rights and corruption as examples. The latter example leads me to a major concern of this paper: the examination of Gyekye's analysis of morality and law enforcement, and my subsequent rejection of his idea of moral revolution as the most effective way of tackling corruption and, thus, ensuring good political morality.

\section{Political Morality and Moderate Communitarianism}

In this section, I explore how Akans, whose society is apparently moderately communitarian, seek to uphold ethical standards in politics. The ideas of 'personhood' and 'communitarianism' (or, specifically, moderate communitarianism) which both have

\footnotetext{
Matolino $(2009 ; 2011 ; 2014)$.

${ }^{6}$ Famakinwa (2010).

7 Ajei (2015).

8 Akans constitute the largest ethnic group in Ghana.
} 
moral underpinnings, are discussed with the view to showing not only how they tend to promote the well-being of people in the Akan community, but also how efforts aimed at promoting them are hampered by some conception of political morality in Akan culture. I will also propose solutions to the problems caused by this latter conception through a deeper interrogation of Akan values. I intend not only to strengthen Gyekye's view (which is contested by some, however) that Akan society is moderately communitarian, but also his attempt at forming a communitarian basis for political morality.

In an attempt to delineate the social structure of the African community, many philosophers or scholars have sought to contrast it with the Western social setting, describing the latter as liberal. The former, however, is portrayed by the authors mentioned in the first paragraph of the introduction as communal and not individualistic. Mbiti, for instance, stresses this in his assertion that in an African society, an individual can only aver that "I am because we are; and since we are, therefore I am. ${ }^{\prime 9}$ while Menkiti maintains that between the community and the individual, it is the community which plays a crucial role in the "acquisition of personhood." ${ }^{10}$ But the apparent suppression of individualistic elements and the role of the individual in the acquisition of personhood led Gyekye to introduce the thesis of moderate communitarianism.

Moderate communitarianism, according to Gyekye, is the idea that although the Akan or African society is communal, it also allows some level of individuality - that is, the society is not strictly communal. ${ }^{11} \mathrm{He}$ contrasts this characterisation of the society with radical communitarianism which he attributes to scholars such as John Mbiti and Ifeanyi Menkiti. ${ }^{12}$ In Gyekye's view, they portray the African society as entirely communitarian, giving little or no room for the expression of individuality. ${ }^{13}$ But using the Akan community as an example, Gyekye explains that there is some recognition of individual rights, ${ }^{14}$ individual "idealistic proclivities", ${ }_{1}^{15}$ individual autonomy ${ }^{16}$ and the capacity of the individual to determine life choices for herself. ${ }^{17}$ However, J.O. Famakinwa (2010) and Bernard Matolino (2009) have criticised the distinctions made between moderate and radical versions of communitarianism, stressing that the versions are the same (especially, in terms of the way they both reject individual rights when they (the rights) clash with communal duties). But I reject this reason, in addition to a few others given by Matolino, as inadequate for equating the two versions of communitarianism. I argue that moderate communitarianism has other features that still make it different. ${ }^{18}$ It can nevertheless be said that the individual, in these African communitarian frameworks, is expected to lead a moral life and ensure the community's good in order to become a person. Personhood, then, is an indispensable concept to the thesis of communitarianism.

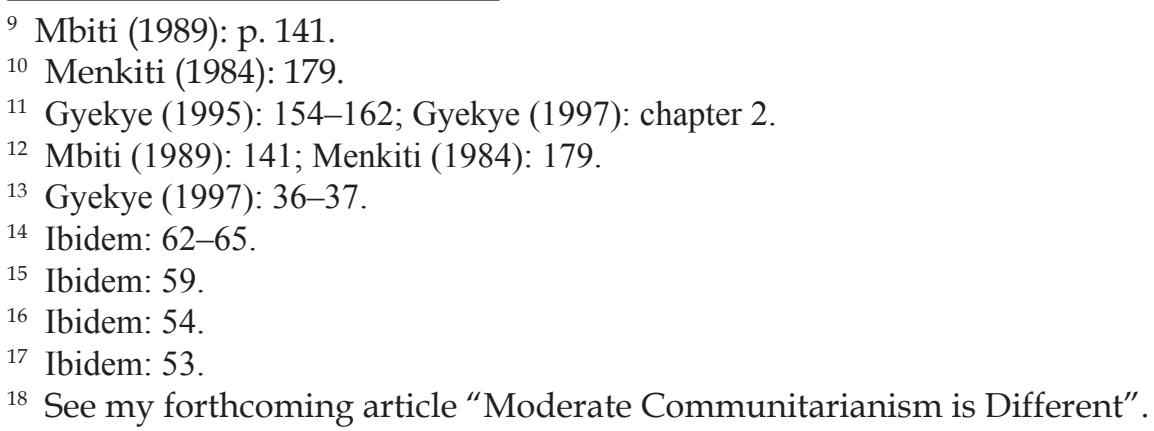


Any talk of 'political morality' initially appears misplaced given the fact that morality is often conceived of in a general sense of right and wrong, such that what is deemed to be moral or immoral is so considered because it either meets moral expectations or offends the moral sensibilities of humans. In this manner, that which is moral or immoral is not determined on the basis of the sphere of life - political, economic, social, religious, etc. - in which it falls. Yet, there have always been remarks suggestive of the idea that there is or could be some special kind of morality applicable to the field of politics. Such morality would be different from that which is deemed moral in ordinary life. This view would, therefore, contrast with the position that politics must generally conform to moral standards.

Akan culture exhibits these contrasting senses of morality in politics and I will first discuss the idea of a special sense of political morality. This idea is similar to the question of 'dirty hands' thoroughly discussed by C.A.J. Coady in his essay Politics and the Problem of Dirty Hands, which was first published in 1991. The idea of 'dirty hands in politics' is explained by Coady as follows:

Those who refer to the necessities of politics have, at least since Machiavelli, often thereby signified not only necessary risks of an apparently immoral kind but necessary lies, cruelties or even murders. Taking their lead from Sartre's play of the same name, modern philosophers tend to talk of the necessity for 'dirty hands' in politics, meaning that the vocation of politics somehow rightly requires its practitioners to violate important moral standards which prevail outside politics ... Often this is bolstered by appeals to the notion of role morality, with some implication that the political role exclusively or predominantly generates the need for dirty hands. ${ }^{19}$

It could be inferred from the quotation that this special sense of morality has the tendency to moralise that which in politics is apparently immoral. And, like the promoters of any reasoned opinion, an individual or philosopher who calls for such morality would somehow expect others to endorse, tolerate or at least acknowledge (the need for) it. This attitude toward political morality is also evident in Akan thought. For instance, there is a famous Akan saying se ye'ton tumi a, ton w'aberewa na to; na wonsa ka tumi no a, wode aksgye no, which means: "if power is being sold, you can sell the old lady of your family in order to purchase it so that when you attain power, you may then use it to take back the old lady." I must first caution that

${ }^{19}$ Coady (1993): 373-374. As Kai Nielsen succinctly writes in his article There is No Dilemma of Dirty Hands, a politician "may do things that in normal circumstances would be horribly wrong, but, in these circumstances of dirty hands, they are not, everything considered, wrong." Nielsen (2000): 141. He basically argues that a politician has to compromise and do evil in order to do good. Some recent political theorists have suggested also that the law may sometimes free politicians at will within the context of political morality. For instance, in his discussion of the political morality of constitutional federalism of the United States, Daniel Halberstam observes that within this context of governance, political morality "like that of international relations, is currently dominated by the view that power may be exercised at will." Halberstam (2004): 833. Even though, he adds, "the Constitution may have set up the institutional architecture to help contain power politically," it "does not temper power with responsibility." Halberstam (2004): 833. 
(i) The selling of an old lady should not be misconstrued as implying a lack of respect for women. However, it appears to portray how political power could be used to obtain that which is precious (as signified here by an old lady).

(ii) The saying does not mean that Akan thinkers would idealise the arbitrary use of political power by rulers because Akan culture has many democratic features. For instance, it chooses chiefs through some form of election (albeit popular elections), grants many individual freedoms, and has great respect for human dignity.

However, the saying has some negative unintended consequences since it has the potential of being used by some to justify their wrongful use of political power. The saying, such people would argue, purports to urge power seekers to see as understandable or morally good the act of getting back what they have lost to others, through the use of the power at their disposal. It is worthy of note, however, that the precious person (or thing) is not just 'lost' but deliberately given away for seemingly tactically selfish reasons. So encouraging those who wield power to use it to re-acquire what they have lost (or literally traded off) is tantamount to an endorsement of immorality in politics. Secondly, and more importantly, the thinking behind the saying appears to be that power, very often coercive power, can be used to acquire anything that the politician desires. ${ }^{20}$ The Akan word for power is tumi which sometimes means more than political power. It could, for instance, mean mystical power or, simply, any form of authority, such as the one which a parent has over her children. Nevertheless, the saying is not used by Akan speakers in connection with parental authority but, sometimes, they use it in relation to mystical power.

In a political context, the power-wielding person is not literally said to get back the old lady through negotiation - and even if there is some seeming negotiation, she is expected to have her way as a result of the position she holds. Consequently, the saying appears to fly in the face of democratic principles, especially the right of an individual to own and dispose of property, and even freedom of choice. It is therefore ironic that Akan culture, a culture that recognises the need for, and actually takes steps to promote, individual freedoms (alongside communal values) would also encourage the occasional use of force to attain one's ends. Outside the field of politics, the use of force against the other is not at all considered as an understandable act. Why is there, one wonders, some concession for this in politics? Inspired by this saying, aspirants to a throne or chieftaincy position would not only be tempted to adopt foul means but might, upon the assumption of the position, also display egoistic and despotic tendencies. Indeed, the apparent prescriptive character of the saying seems to imply that, in the literal sense, people should understand the moral duty of the power-wielding person to have her 'old lady' back (after failing to protect her temporarily) through the abusive use of power. And in the proper sense of taking 'the old lady' to mean 'a valuable thing', the saying could still be interpreted as an admission that power-seeking individuals may need to recoup (valuable) investments made before their attainment of power when they succeed in their quest for power. But recouping this investment may result in the misapplication of public resources to the advantage of such

\footnotetext{
${ }^{20}$ I grant exceptions to 'things' that are beyond human control and thus cannot be acquired by political or any form of human power; such as life.
} 
individuals. ${ }^{21}$ Hence, the saying also has the potential to invite some corruption into Akan politics, even though this is generally frowned upon in Akan culture. ${ }^{22}$

The second sense of morality evident in Akan culture is the idea that a ruler or anyone in political authority ought to observe the standards of morality in the performance of their 'official' duties. Consequently, it is a rejection of the normalisation of the immoral in political practice, as it seeks to ensure the communal good. But in a moderate communitarian context, ensuring the good of the community implies promoting the welfare of the community without necessarily ignoring the rights of the individual. Moderate communitarianism offers protection against the degeneration of morality that may result from such normalisation, as in a ruler's promotion of her personal interest in the guise of those of community members. This means that the concept of moderate communitarianism allows a comprehensive promotion of welfare since the community and the individual are both the focus of the actions of the political agent. Besides, since individuals living in such a communitarian society are only regarded as 'persons' when they commit themselves to the communitarian ideal of doing good to humans, moderate communitarian ethics promote morality in both politics and society as contrasted with the pro-dirty-hands morality discussed above (and exemplified in Akan culture by the idea of 'selling an old lady').

Together with the concept of personhood, therefore, moderate communitarianism constitutes a formidable basis of political morality. For the Akan is urged to have a communal orientation to ethics in politics, knowing that a person's commitment to the performance of morally right actions alone earns her the status of personhood in the community. Consequently, if a political actor such as a ruler engages in egoistic, autocratic and corrupt practices (as implicit in the selling of the old lady and generally accommodated in pro-dirty-hands morality), it would negatively affect her personhood qualifications. Secondly, performing such bad actions would ultimately affect the moral authority of the ruler in the eyes of the people. This undoubtedly would bring issues of trust. Thirdly, a ruler, in order to earn the support of her people, must respect traditional values regarding the equality of human beings. It is often said, for instance, that nipa nyinaa y\& $p \varepsilon$ (all humans are equal) $)^{23}$ - but this saying can be given its true meaning if the

\footnotetext{
${ }^{21}$ One special sense in which the saying is sometimes used is when one is being advised to vie for a position of leadership in an organization, association or a political party. Here, still, the expectation is that one may benefit materially by some abusive use of power. Corruption and other political vices have been the bane of Ghanaian contemporary democratic practice. This situation is indeed true of many African countries. In his chapter, "Political Corruption: A Moral Pollution", Gyekye discusses how the perception of the erstwhile colonial administrations in African countries by Africans as alien (as the Other) and argues that many Africans today have similar perceptions about their governments and institutions of government. The latter are thus seen as distant bodies from which resources must be taken - often illegally - to the benefit of one's family or oneself (Gyekye (1997): 195). With an already bad situation like this, the Akan saying could only be harmful to the quest by the Akans, Ghanaians, and to some extent, Africans to improve their economic, social and political standing.

${ }^{22}$ Starting from the end of the next paragraph, I show some implications of the selling of 'an old lady' for the concept of moderate communitarianism.

${ }^{23}$ This makes Rawls' claim that the idea of all humans being free and equal is a liberal idea incorrect (Rawls (1999): 66 cited by Ajei (2015): 495). The presence of the idea of human equality in African philosophy is confirmed by Mogobe Ramose in his (2001): summary. This suggests that one can hold the idea without necessarily being a liberal.
} 
ruler does not take things from others (forcibly), just as ordinary individuals should, by virtue of this saying, not allow themselves to be cheated or disturbed by others. Finally, the moderately communitarian Akan social system has a way of checking the excesses of power, whereby the selected chief is made to swear an oath upon assumption of that position to be fair to all and, also, protect the community, its resources and traditions. ${ }^{24}$ The people before whom the chief swears are allowed by custom to depose the former if she goes against the oath. It is important that the people continue to enforce this custom strictly in order to get the best from their rulers and continue to act in line with the promotion of the common good and the ethic of moderate communitarianism. To ensure these, therefore, the people always show unalloyed interest in the activities of rulers. This attitude is undoubtedly an essential part of Akan politics.

Moderate communitarianism aims at, among other things, the achievement of social harmony and trust in one another. It encourages one to support and be counted upon by the other, and vice versa. An Akan ruler who engages in the bad practices mentioned above would be exhibiting behaviour inconsistent with the ideals of moderate communitarianism because, while urging her people to be always interested in the well-being of all, she can only pretend to be doing so as egoistic, corrupt and despotic acts or tendencies never serve the public good and therefore defeat moderate communitarianism.

Moderate communitarianism thus becomes a viable political concept for at least three reasons. First, it provides a comprehensive understanding of the social identity and status of the individual, and the relation that obtains between her and the community. For the individual realises that she is also a social being, and that the community has some rights over her just as she has over the community. This differs from the liberal conception of the relation between the individual and the community where the rights and identities of the two are often presented as antithetical. Secondly, the concept, even though communally oriented, accommodates some rights of the individual. Thirdly, the concept is consistent with democracy since it accommodates virtues such as equality, fairness, value for human dignity, freedom of choice, freedom of thought, freedom to own property, and commitment to the promotion of the common good..$^{25}$

\section{Negotiating Political Morality in a Democratic Framework: Lessons from Moderate Communitarianism}

My objective in this section is to examine how political morality could be negotiated in a democratic framework, focusing especially on political leadership.

Many African countries now practice or appear to have adopted a system of governance modelled around Western forms of multi-party democracy. There are periodic elections and separation of powers in these countries, however imperfect they are, yet citizens of these countries continue to have ethnic cleavages. Traditional systems of governance also exist; meaning that in a country like Ghana where Akans can be found and whose community moderate communitarianism is a feature of, the average Akan

\footnotetext{
${ }^{24}$ In the Akan thought, traditions are subject to some revision.

${ }^{25}$ See, for instance, Gyekye (1997): 149-157; Gyekye (2004): 57.
} 
lives under the influence of two systems of governance: Western style democracy and the indigenous moderate communitarian model ${ }^{26}$ It is quite noticeable that contemporary democratic practice in Ghana and, indeed, many African countries, often facilitates the election of individuals who have gone through Western educational systems to political office. And, it would be realistic to expect that such individuals would also govern under the influence and with the awareness of the two systems of governance just mentioned.

Since Mbiti, Menkiti and Gyekye agree on the communitarian outlook of the African society - diverging only in terms of degree - one would expect that the average contemporary African leader or public official, being an African, would be community or people oriented. But the performance in office of these individuals in terms of promoting the well-being of their citizens has not been quite impressive. This is particularly so given that it is these political leaders and public officials who, having acquired some Western education, have been in charge of the administration of their countries and, thus, of very huge national resources. Without denying that an uneducated African could also become individualistic, it could be asserted that increasing Western education (when it leads to the adoption of Western lifestyle) and urbanization tend to make people more individualistic, less communitarian. ${ }^{27}$ On this basis, one would have thought that an elected African leader who has some individualistic orientation would, at least, do well at protecting the rights of individuals. Yet there is not much to show that they are able to achieve this. Consequently, and yet ironically, having an individualistic attitude does not necessarily lead one to the promotion of individual rights and well-being of citizens. There are several areas in African democratic practice where this deficiency is most visible, but for the purposes of this piece, I discuss only two as examples: human rights and corruption. I also discuss how moderate communitarianism could help address these. Two Akan moderate communitarians who have identified and proposed separate solutions to the problems are Martin Ajei and Kwame Gyekye.

Human rights, Ajei explains, "proclaim rights which, when observed, lead to humanly liveable life. These norms are rendered as entitlements and responsibilities that accrue to human beings by virtue of their being human." ${ }^{28}$ His reason for suggesting this is that "the entitlements and responsibilities arise from the premise that being human confers an intrinsic value and dignity from which these rights derive; and that a fulfilled and dignified human life would seem to necessitate the realisation of the claims inherent in these entitlements and responsibilities." ${ }^{29}$ He also attempts to situate human rights within the African context arguing that the debates among African philosophers, especially from the angle of the International Bill of Human Rights (IBHR), are generally two-pronged: one group argues that the IBHR is fundamentally Western and is likely to face implementation challenges in African cultures, while the other group argues that

\footnotetext{
${ }^{26}$ This influence is true of the other Ghanaian ethnic groups as well.

${ }^{27}$ This does not mean that there have not been individualistic and even non-communitarian Africans. In the past, some bad African chiefs collaborated with Europeans to 'sell' fellow Africans into slavery. In Ghana today, there are allegations that some chiefs collaborate with illegal surface-miners of gold in their Chiefdoms, destroying farm lands and polluting water bodies as a result. The allegations are not yet proven, though.

${ }^{28}$ Ajei (2015): 491.

${ }^{29}$ Ibidem.
} 
these laws - which are understood by Ajei to contain "modern human rights values" are not entirely inconsistent with long held values in many African cultures. ${ }^{30}$

Ajei makes many good observations including the view that the community does have rights, a fact which is not often stressed in the African communitarian literature. In relation to the Western, liberal non-communitarian foundations of the IBHR, he asserts, "the norms enshrined in the IBHR derive principally from liberal conceptions of the person and society, which tend to prioritise civil and political rights over economic and social rights, and the rights of community." ${ }^{31}$ The fact that only one of the thirty articles of the Universal Declaration of Human Rights (UDHR) mentions duties which an individual owes to the community ${ }^{32}$ solidifies Ajei's observation. Another good thing about Ajei's work is that he attempts alongside Gyekye ${ }^{33}$ to (re)construct human rights from an African, moderate communitarian background.

However, there are a few comments that I would like to make about his interpretations of communitarianism, Gyekye's views and Akan philosophical ideas in reference to human rights. After expressing my views on these, I will relate the discussion to moderate communitarianism. In providing what he calls "the theoretical basis of an integrative notion of a person," which moderate communitarianism provides for an African conception of personhood, he affirms that moderate communitarianism is "rooted" in "metaphysical and moral concepts." ${ }^{34}$ But having already discussed aspects of the moral foundations of moderate communitarianism above, it is opportune to examine arguments like Ajei's that concern the metaphysical. Ajei states that "Akan ontology postulates three metaphysical constituents of a person, which straddle the physical versus the non-physical realms of being" - naming them as the skra, sunsum and mogya. ${ }^{35}$ Referring to Gyekye for the interpretation of these "constituents", Ajei describes (i) $\mathrm{skra}$ as a life principle which originates from God, ${ }^{36}$ (ii) sunsum as a "universal power" 37 and "a person's conscious energy," 38 and (iii) mogya as "the physiological basis of an individual's life. ${ }^{39} \mathrm{He}$ then concludes that all these elements, in addition to being identifiers of the person also "play pivotal roles at the social level." ${ }^{40}$ Some of these roles

${ }^{30}$ He cites in support of the former Ake (1978): 5-8; Cobbah (1987): 311, 314, 316, 324, 326; Shivji (1989): 88-89 and in support of the latter, Wiredu (1990): 250-257; Gyekye (1996): 149-150, Mubiala (2010): 214-218.

${ }^{31}$ Ajei (2015): 492. This sentence should not be misconstrued as a complete denial of the presence of the notion of community in the IBHR and even other liberal-inspired declarations such as the Universal Declaration of Human Rights (UDHR). The sentence only means that there is an inordinate concentration on individual rights, in a manner that belittles other - especially community - rights. And that, "if the intention of the instruments of IBHR and the Vienna Declaration was to affirm the equality in status of all the rights of human beings, then this intention is defeated" because significant aspects of these "contrive to depict a hierarchy of rights in favour of the civil and political rights of individuals." Ibidem.

32 Ibidem.

${ }^{33}$ See for instance Gyekye (1992): 113-121.

${ }^{34}$ Ajei (2015): 497.

35 Ibidem.

${ }^{36}$ He cites Gyekye (1995): 87-94.

${ }^{37}$ He quotes ibidem: 72-73.

${ }^{38}$ Ajei (2015): 39-42.

${ }^{39}$ He attributes this to Gyekye (1995): 85.

${ }^{40}$ Ajei (2015): 497. 
will be mentioned in the course of this paper. The realisation of the social dimensions or implications of the metaphysical constituents of a person is quite commendable because Ajei, then, does not ignore the social character of communitarian ethics - which invite the individual to make herself useful to the community.

The problem concerns the ontological status of mogya, especially as Ajei attributes it to Gyekye. First, an obvious error that he makes, which I do not think is deliberate, is that what he attributes to Gyekye cannot be found on page 85 of Gyekye's Essay on African Philosophical Thought as stated. However, on page 94, where mogya is mentioned, it is not placed in the same category by Gyekye as skra and sunsum. For, according to Gyekye, skra and sunsum are "definitely of divine origin." ${ }^{41}$ Gyekye rather translates mogya as "blood" which, together with ntoro (not translated by Gyekye), are explained as "genetic factors responsible for inherited characteristics." ${ }^{22}$ Mogya and ntoro are derived, respectively, from one's mother and father. Gyekye should therefore be portrayed as someone who either does not recognise these non-divine aspects as real ontological constituents and I think he does not - or as recognising all four (okra, sunsum, mogya and ntoro). It is unclear, nonetheless, why Ajei did not account for or explain Gyekye's position on ntoro in his paper. In spite of this, Ajei's statement that mogya is "an adhesive for social bonding," 43 a view expressed also by Kwasi Wiredu, ${ }^{44}$ is quite correct because Akans are matrilineal and, at the clan level, identify with 'blood' (that is, maternal relations).

In linking his analysis of skra, sunsum and mogya to the issue of human rights, Ajei states - following James Silk, Gyekye and Wiredu - that these 'metaphysical' aspects of the (ontological) person demand categorically the dignified treatment of the human being. Silk and Wiredu point out that this conception is a crucial element in the African perspective on human rights. As Ajei writes

According to James Silk, the ontological approximation of the idea that the human being possesses a speck of the nature of God, as occurs with okra, is ethically significant, and translates into the secular reasoning that the individual possesses attributes that are inviolable.

Likewise, in Gyekye's moral philosophy, every person has an intrinsic value, equal in each human being, by virtue of the joined activity of the skra, sunsum, and mogya. skra entitles every human being to a certain basic respect as a birth right. ${ }^{45}$

Once again it is difficult to endorse Ajei's inclusion of mogya in the statement above which mentions Gyekye. For, in accordance with Silk's view, Gyekye argues that skra and sunsum have a divine origin; but he (Gyekye) denies that mogya has. Rather he states that mogya derives from the mother. I am also not convinced, given Gyekye's position on mogya, of the plausibility of claiming a human right on the basis that one has inherited some (ge-

${ }^{41}$ Gyekye (1995): 94.

42 Ibidem.

${ }^{43}$ Ajei (2014): 48-49; Ajei (2015): 497.

${ }^{44}$ Wiredu (1996): 158.

${ }^{45}$ Ajei (2015): 497-498 
netic) characteristics from one's mother. However, an objection may here be raised that the divinity of mogya could be sustained if mogya is literally taken to mean physical blood - such that humans, being blooded beings, are ultimately deemed to have their origin from God (their creator). But such a physical conception of 'blood' would have the following negative consequences: (i) this conception of mogya would not be consistent with Silk's argument for the infrangibility of human rights - an argument which Ajei labels as metaphysical, (ii) Ajei would not be right in likening Gyekye to Silk since the former, on the contrary, endorses the mundane character of mogya, and (iii) it will wrongly include non-human animals to also become objects of human rights, since they have God-created blood in them.

But just before I relate the discussion of human rights to moderate communitarianism, I must use this paragraph in pointing out that the ontological conception of a person in Akan philosophy includes one important element which has so far been missing from the discussion. It is honam or nipadua, "the body" ${ }^{46}$ It is not quite clear why the above philosophers ${ }^{47}$ especially Wiredu who rejects a purely metaphysical conception of the ontological parts mentioned by Ajei above ${ }^{48}$ in favour of a near-physical conception, did not take the advantage of incorporating fully the constituents of a person in Akan ontology into the debate on human rights. ${ }^{49}$ This comment stems from their conspicuous neglect or suppression of honam in the human rights debate. It may accordingly be asked whether the body (perceived as an aspect of a person) or understood to constitute the entirety of a person may not in itself give rise to the need to treat the human being with dignity? My answer is that it may; in fact, it should. Conceiving of a person, even in the extreme sense, as purely physical is not antithetical to observing the rights and dignity of others. I must caution against an attempt to label this position as Western because that would be incorrect. Indeed, there are some indigenous Akan thinkers who do not have Western Education (and are not really influenced by Western thought) but they hold a purely physical conception of the person. ${ }^{50}$ And it would be unreasonable and baseless to suggest that such thinkers would have no idea about or respect for human dignity. My argument is that the honam, in addition to skra and sunsum, should contribute to the development of an ontological basis of human rights. Without necessarily appealing to skra and sunsum, it is possible to regard as offensive the physical scenes of someone being deprived of her property, a human body being mutilated or an individual being sexually abused. Consequently, Silk, Wiredu, Gyekye and Ajei seem to concentrate unduly on the non-bodily conception of the human being in formulating the ontological framework for human rights. And this negatively affects Ajei's presentation of human rights from a moderate communitarian point of view.

\footnotetext{
${ }^{46}$ Wiredu (1983): 119; Gyekye (1995): 85.

${ }^{47}$ I mean Silk, Wiredu, Gyekye and Ajei. Note that Gyekye also explicitly links okra with human rights. Gyekye (1997): 63.

${ }^{48}$ Wiredu (1983): 119-121; see also Majeed (2013): 25-26.

${ }^{49}$ In spite of Wiredu's rejection of the spirituality of the 'constituents', it is difficult to see how mogya could perform this bonding role and for $\mathrm{kra}$ and sunsum to be bases of moral action (and thus influence the moral identity of the human being) and still be devoid of any metaphysical considerations. Nonetheless, the human being is made to take account of them and the body as well when acting in moral terms. The ontological and moral identities of a person are sometimes linked, though logically separable. ${ }^{50}$ An example is Nana Boafo-Ansah (Gyekye (1995): 48). Views from such individuals do not constitute those of the majority of African thinkers, though.
} 
Moderate communitarianism grants both individual and community rights but they have physical and metaphysical dimensions. The physical ones may include rights that are material or emotional in character, such as an individual's right to work, own property and have a family, and the community's right to acquire property and maintain its existence. The spiritual ones are the rights of both parties to seek their spiritual well-being, given the Akan belief that this world is spiritual as well and thus human/community well-being could be promoted spiritually. ${ }^{51}$ Given the Akan dualistic conception of the world, it could be observed that Gyekye and Ajei's concentration on metaphysical elements of the individual in their discussions of the basis of human rights is not only narrow as I stated above, but the spiritual rights of the traditional communitarian society does not receive much attention in their works. I therefore add to their philosophies toward a fuller account of rights in the communitarian framework.

From the moderate communitarian perspective, therefore, the following lessons are offered to the modern democratic state: first, in considering the metaphysical basis of human rights, the mogya should not be included for its entitative status, ${ }^{52}$ although it has the capacity to bond members of the community; secondly, the state should not necessarily see the basis for human rights in the spirituality of the individual; thirdly, with the body as a factor that warrants the right treatment of the human being, the state has more reason than divinity (of soul or spirit) to respect and promote human rights. In spite of the foregoing, a contemporary democratic African state should be cautious in adopting from moderate communitarianism, if it needs to, the right to seek or promote its well-being in a spiritual manner. For, doing so might end up with the introduction of full-scale religion into state affairs, rolling back some advancements in democratic governance which have been fuelled for years by the separation of state from religion. Finally, since the values of human rights exist in Akan culture and moderate communitarianism "proclaims" that "human dignity makes human rights morally non-derivative," ${ }^{53}$ politicians and public officers (especially) are by virtue of their positions supposed to adopt the principles of moderate communitarianism. For, as a result of "its ontology of the co-originality of person and community, moderate communitarianism is a better foundation for welfare because it is apt to be more hospitable to socio-economic rights than theories of moral individualism are likely to be." ${ }^{54}$ I therefore agree with Ajei that "human welfare is the root of political morality." ${ }^{55}$ Accordingly, politicians and public officers lose the moral basis to function when they engage in acts that infringe on the rights of citizens, hamper the promotion of their welfare or have the potential to make

\footnotetext{
${ }^{51}$ At the modern democratic state level, even though the state does not interfere with an individual's seeking of her spiritual well-being (except when it breaks other civil or constitutional laws), the state does not see it as its mandate to lead citizens in seeking spiritual solutions to national problems. Yet, this attitude is quite often contradicted. In Ghana, some national programmes are started and closed with prayers by representatives of Traditional African, Islamic and Christian religions. Also when there are national crises and soccer tournaments, elected governments often appeal to these religious bodies to pray for the nation.

${ }^{52}$ That is, if we are to go by Gyekye's analysis.

53 Ajei (2015): 500.

${ }^{54}$ Ibidem: 499; my italics.

${ }^{55}$ Ibidem.
} 
it difficult for citizens to exercise their rights. Moderate communitarianism is therefore a plausible concept when it comes to ensuring human welfare and good political morality.

The second area in the African political space where leaders have not performed so creditably and which requires the benefit of moderate communitarianism is political corruption. Gyekye defines political corruption as the "illegal, unethical, and unauthorized exploitation of one's political or official position for personal gain or advantage." 56 Usually, this is done to the detriment of the majority of the population. Political corruption, which of course is both an economic crime and immoral, continues to be a major problem for many contemporary African countries - which are also democracies. ${ }^{57}$ The adoption of multi-party democratic systems after colonialism has really not translated into the enhancement of rights and the economic well-being of citizens. Some scholars also see the processes leading to the election of public officials as the major cause of the difficulties of the African political economy. Explaining how corrupt people get elected and perpetuate themselves after elections through corrupt means, Ani observes

Money politics harbours the tendency to relegate the more urgent issue of the character of candidates for public office to the background, especially where the capacity to win is roughly correlative with financial capacity. This point should be quite worrisome if we consider that there are many illegitimate ways to make money. The objectives of culprits in this regard is to attempt, as much as possible to relegate 'reason' or 'rational justification' to the background by means of superior and robust funding. ${ }^{58}$

While Ani proposes "deliberation" (or "deliberative democracy") and "fact-checking" as the way forward, the moral context within which corruption falls leads some to suppose that the solution to the problem of political corruption should equally be moral. Gyekye shares this latter view. ${ }^{59}$ Moderate communitarianism indeed provides the moral awareness needed by a politician or public officer about the unacceptability of corruption. However, if the implications of personhood and communitarianism are not closely looked at, one may render an ineffective conception of morality as a solution. This is a weakness I identify with Gyekye's position and I explain it in the next section. But, while affirming Ani's view which tends to hint of vote-buying as a crucial element of political corruption, I need to bring out an emerging trend, at least in Ghana, where some individuals who receive money and other items of inducement from corrupt officials are still able to vote against them. And if the electorate continue on this path, vote-buying will someday cease to be a major problem. I accept also Ani's view that African leaders must be "subjected to serious public pressure to give account of their stewardship." 60

\footnotetext{
${ }^{56}$ Gyekye (1997): 193.

57 They are best described by some as mere "aggregative democracies" (Ani (2013): 207) or as following a Western styled multi-party system. By aggregative democracy is meant "the institutionalisation of voting as a basic standard for decision-making, instead of its usual function as being the last resort in cases of intractability or failure of consensus." Ani (ibidem): 208.

58 Ani (ibidem): 215.

${ }^{59}$ Gyekye (1997): 206-208.

${ }^{60}$ Ani (2013): 216.
} 


\section{Gyekye on Political Morality and Law Enforcement}

In order for there to be political morality, Gyekye discusses factors that, in the thinking of many social scientists, explain the prevalence of corruption in Africa. These include the fact that public officials are often corrupted by the political system, ${ }^{61}$ weak leadership, ${ }^{62}$ the perception of government as an entity which is distinct and distant from citizens, ${ }^{63}$ the African social system, ${ }^{64}$ bad economic conditions of Africa, ${ }^{65}$ and "lack of an adequate legal and institutional framework or controls." 66 Gyekye then suggests that looking for a solution to the problem of political corruption from the angle of any of these factors would not bring any real success. For, political corruption is rather a moral problem. In this regard, he proposes, there must be two forms of moral revolution in Africa. First, there must be "fundamental changes" in "moral beliefs, values and ideals ... i.e. inauguration of new moral paradigms and, consequently, the replacement of the old." ${ }^{67}$ With new moral paradigms, according to Gyekye, Africans will be able to change their attitudes toward government, public property, public resources, and public office. ${ }^{68}$ Secondly, there must be "a new and positive commitment to known and accepted moral rules and principles." 69 He calls the former substantive moral revolution and the latter commitmental moral revolution..$^{70}$ But he argues that commitmental revolution is the more pressing and fundamental because "while substantive moral revolution will not be necessary" provided that "the existing moral beliefs and values are held, or should be held as adequate", it is not so with commitmental moral revolution. Commitmental moral revolution, "as a means of counteracting people's moral weaknesses, will be necessary, since for most people the gap between moral beliefs and moral commitment is a yawning gap."71

Gyekye's argument has some strengths. It properly identifies corruption as a moral problem and also recognises that the two forms of revolution need not occur at the same time (since commitmental revolution would not call for substantive revolution). He also notes correctly that the two revolutions do not bring each other about (since, for instance, substantive revolution would not necessarily make a moral agent commit more to moral principles).$^{72}$ But there is a further explanation to the rejection of the joint-occurrence of the revolutions which Gyekye could have given. While substantive revolution requires that changes be made to the core moral values and ideals which underlie moral principles held by Africans, commitmental revolution encourages Africans to maintain the existing moral principles. If the changes suggested in substantive revolution are really

\footnotetext{
61 Gyekye (1997): 194

62 Ibidem: 194-195.

63 Ibidem: 195.

64 Ibidem: 195-196.

65 Ibidem: 196-197.

66 Ibidem: 197.

67 Ibidem: 206; my emphasis.

${ }^{68}$ Ibidem: 208.

${ }^{69}$ Ibidem: 209.

${ }^{70}$ Henceforth, I refer to (i) and (ii) by these names.

71 Ibidem: 214.

72 Ibidem: 212-215.
} 
fundamental, and there is "a replacement of the old" paradigm, logically, there would no longer be "known and accepted moral principles" to commit to.

There are problems, however, with Gyekye's argument and his understanding of the causal explanations for the incidence of political corruption in Africa. In particular, Gyekye underestimates the causal efficacy of law enforcement. Gyekye begins the explanation of his position on law enforcement in the fight against political corruption as follows:

The lack of an adequate legal and institutional framework or controls may also explain the widespread incidence of political corruption... since they seem to make it possible for some public officials to feel that they can commit corrupt acts with impunity. The assumption here is that if the appropriate sanctions and controls are instituted and the powers and the activities of the law enforcement agencies are expanded, political corruption will be considerably reduced, if not eradicated. This assumption, however, may be only partially true... ${ }^{73}$

Gyekye acknowledges that law enforcement can contribute to the fight against political corruption but insists it is not what will reduce corruption considerably or eradicate it. The crucial causal explanation is, in Gyekye's view, "the moral circumstances" of the individual. Political corruption, therefore, "is crucially a moral problem and should be grappled with from that standpoint." 74 The question here is: To what extent, if at all, does Gyekye see law enforcement as part of the moral way of grappling with the problem of corruption? Or does he see law enforcement to be like any of the other solutions (such as improvement in political, social and economic conditions of people) that, when put in place, cannot control corruption effectively because individuals involved in it still need to avoid greed and commit to moral principles? An answer to the second question will easily provide one to the first. In relation to the second question then, Gyekye responds in the affirmative and describes social scientists who propose law enforcement as a therapy for political corruption as having offered a "mere nostrum".${ }^{75}$ His reason is that "the effective enforcement of the law will ultimately depend on the probity and moral uprightness of the law enforcement agents." ${ }^{\prime 6}$ So, instead of the nostrum which is offered by the social scientists, he offers the "realistic" and "ultimate" solution: morality. ${ }^{77}$

But my point is that Gyekye is not too far from the proponents of law enforcement whom he criticises because law enforcement in relation to political corruption can never be devoid of morality in the first place. If, for instance, a law enforcer who apparently is not (personally) morally strong is compelled by law to stop a corrupt act somewhere, whether or not this law enforcer is personally moral, he would still have

\footnotetext{
${ }^{73}$ Ibidem: 197.

${ }^{74}$ Ibidem: 201.

75 Ibidem: 215.

${ }^{76}$ Ibidem.

77 Ibidem. His point is that if we commit to moral principles, then we will be able to use it to enforce the law; but not the reverse. This accounts for his introduction of the word "legal" in his concluding statements on the meaning of commitmental moral revolution as: when there is commitment to accepted moral (and legal) rules and prescriptions. Ibidem.
} 
done something that has moral implications. On the other hand, if this same person were morally committed and went out to stop the corrupt act, then both the person and her enforcement of the law would be moral, even if in different ways. In favour of the law, I would add that where measures or policies are designed by the state in such a way that they make it difficult for law enforcers to disobey laws on corruption, the state will be dealing realistically with political corruption, contrary to Gyekye's thinking. For, as Gyekye rightly notes, people cannot be made moral individuals through legislation because moral commitment is essentially an individual act. How then can the state be advised to control or stop the activities of corrupt citizens through a method (that is, moral commitment) which lies outside the mandate of the state? Apart from that which the state can legislate and enforce, what is left is for the state to urge citizens to commit to morals; but I do not think this is how the state is to deal realistically with political corruption. Gyekye's commitmental revolution is only applicable at the individual level and has worse prospects at the state level. The state can legislate to get law enforcers to work effectively on corruption (and thus do things that are moral or have moral implications) without necessarily seeking to make them personally undergo a moral revolution. Yet, such legislation would really not be amoral. Accordingly, if enforcing the law amounts to acting within a moral context, then how can the one who offers (commitment to) morality be 'really' different from the one who offers a solution (law enforcement) that also includes morality?

Even if the social scientists cited by Gyekye ${ }^{78}$ did not see law enforcement as a question of morality, it should still have been difficult for Gyekye to describe law enforcement as a "mere nostrum" if he had seen that the practical enforcement of the law on corruption fell within the context of morality. For it is quite true that the enforcement, nonenforcement or even the misenforcement of corruption laws is already a moral question that requires neither a further justification with a moral argument, nor contrasting with a moral situation. It is often held that law and morality are two different concepts, except that the concerns of one sometimes run into the concerns of the other. ${ }^{79}$ While holding this view, one might still not have a good understanding of the relationship between morality and law, particularly of the stage where the two are misconstrued to have extended or "overlapped" (Gyekye's word) into each other's concerns. For this position would imply wrongly that an issue such as the enforcement of corruption laws - which may be said to fall within both concerns - is an extension into a separate domain of morality. But the enforcement of corruption laws is always legal and moral at the same time, and does not call for its contrasting with morality (or the moral argument). Thus, law enforcement of this kind is not only a moral matter but, quite substantially, concerns political morality. ${ }^{80}$ It is noteworthy that I do not dispute the fact that political corruption is ultimately a moral problem but I reject the view that resort to the law to fight political corruption is practically inferior, distinct and less effective than a commitment of individuals to do good (or to respect moral principles).

\footnotetext{
78 Particularly, Victor Le Vine. Ibidem: 197.

79 Such as held by Gyekye (1997): 213.

80 Raz (1994): 206.
} 
Another aspect of Gyekye's argument concerning the functions and limitations of the law which also requires my attention is his claim that the law should be used in "forging new moral attitudes," but not in the "enforcement of morals," because although the law is effective "in our responses and attitudes toward moral rules and principles", this effectiveness will not last. ${ }^{81}$ For, he continues,

after it has been decreed that doing $X$ is against the law and is punishable by a heavy fine and a long-term imprisonment, it is up to the individual, now in the know of the demands of the law and the consequences of its violation, to take up a definite stand with respect to action X, whether he should do it or not. And here, in obeying the law, the exercise of the will is the most relevant factor. In the exercise of the will, the law is ineffectual, otherwise we will be involved in a vicious circle. ${ }^{82}$

Gyekye's argument that law enforcement is ineffective in the fight against corruption because it is up to the individual to decide whether or not to break the law is not good enough. It is true that the responsibility to obey or disobey the law is on the individual; but it is the same with Gyekye's revolutionist argument too, especially with the commitmental version which he affirms as the "more fundamental". ${ }^{83}$ Here as well, it is the individual who chooses either to commit or not to commit to the existing moral values.

Finally, Gyekye's resort to morality or the internal will to be moral reduces the fight against corruption to some sort of abstraction - which in itself is not bad but has two major challenges. First, Gyekye does not show the mechanisms of how an individual could become strong willed (or to use Gyekye's words, "steel willed") and how she can know that her will is steeled. Is the will to be steeled through education or some self-acquired knowledge or something else? And if it is to be obtained through education, then what kind of education: religious, secular, theoretical, practical, or other? And, when the will is supposedly steeled, is she going to know it by testimonies of others, divine inspiration, self-consciousness, or checking how she is not caught by the laws of the state? And in connection with state laws, could it not be said, then, that the law precedes morality? The second challenge is that the resort to an internal moral will shows how he misses the point about practically fighting corruption at the individual level. His recommendation that corrupt public officials develop their internal will to be able to end corruption assumes wrongly that there is a public official who is only aware of the immorality of corruption but not the fact that committing oneself to moral principles stops corruption (before it is practised). But the element of commitment is, also, known already to such officials. Hence, if public officials who engage in acts of corruption do so with the knowledge of these, then it seems redundant to suggest this same internal, conceptual solution to them. Other practical measures are needed; and the best of them all is, in my view, the very measure Gyekye attempts to reject - law enforcement. It also encourages public officials to act morally and, yet, has the added advantage of bringing external pressure on the officials to resist the immoral act of corruption. It therefore

\footnotetext{
81 Ibidem: 212-213.

82 Ibidem: 213.

83 Gyekye (1997): 215.
} 
makes it possible for at least some of those who have already failed Gyekye's standard of "commitment" (because they are weak willed or perverse) to be deterred from engaging in corruption - thereby bringing down the number of public corruption cases. This, however, will particularly be achieved when the law is well enforced (such as in the manner suggested below). ${ }^{84}$

I perceive the enforcement of the law as the most effective measure required to make contemporary Africa's democracies fight corruption better. ${ }^{85}$ Ultimately, this measure will make political leaders and public office holders accountable to their people. It would be a misrepresentation to suggest that there already are no civil laws designed to ensure such accountability. But the drive toward accountability will be enhanced if there is (i) a push for the further tightening of such laws, (ii) creation of more awareness among the citizenry of the need to hold their leaders accountable, ${ }^{86}$ and (iii) constant scrutiny of the activities of political leaders (or public office holders in general) by both citizens and state institutions, while ensuring that corrupt officials never go unpunished - as found in Akan politics.

This solution is consistent with the ideals of the value-laden thesis of moderate communitarianism. For, there is a close connection between the law and morality, although they are not always the same. The law indeed seeks to ensure the doing of right and the avoidance of wrong, except that it accommodates both moral and non-moral rightness and wrongness. And laws that relate to public morality cannot necessarily be said to be non-moral, since they are to uphold virtue and ensure public good. Laws against the immoral act of stealing/corruption are moral by every rendering and in the interest of the public. ${ }^{87}$ In the traditional Akan context, we have observed how, for good behaviour and governance from leaders, moderate communitarianism fosters in the people the attitude of vigilance and interest in the workings of leaders. We have also observed how citizens are encouraged and empowered to remove from office a chief who engages in corruption or, generally, acts against the interest of the community. Such a chief is deemed not to have observed the moral prescriptions of both personhood and moderate communitarianism. These same approaches should, in contemporary African

\footnotetext{
${ }^{84}$ It might be objected that the proposal that the law should be enforced also seems redundant (we all know we should enforce the law), and that it suffers from the same redundancy that I accuse Gyekye's moral prescription of (we all know we should be moral). Accordingly, it might then be claimed that I only achieve an aspect of Gyekye's proposal that I reject: whilst Gyekye proposes commitmental moral revolution (let us take our moral codes more seriously), I propose the tightening of law enforcement (let us take our laws more seriously). However, this objection will not hold because beyond proposing that we take our laws seriously, which we all know we should, I propose that: (i) enforcing the law seriously against corruption is at once taking morality seriously (since this law, its enforcement, and corruption itself all fall within the context of morals), (ii) it is erroneous to contrast this law with morality as Gyekye does, and (iii) failure to take morality seriously will result in a state of despair under Gyekye's thesis - but my proposal better equips us to deal with the failure.

${ }^{85}$ Law enforcement is both a moral duty and important feature of moderate communitarianism (even though it is also a legal matter). Apart from the fact that a refusal to enforce the law is a direct incentive for committing crime and immorality, it especially serves in the arena of public morality as a means by public officials to dehumanise citizens.

${ }^{86}$ This admits Ani's proposed solution above.

${ }^{87}$ It is in this sense that some define political morality as "that part of moral theory which deals with the actions of political institutions"; and, this part being "the law." Raz (1994): 206; he quotes R.M. Dworkin's Hard Cases (1975).
} 
democracies, guide citizens and public institutions mandated to deal with corruption to handle non- or ill-performing politicians and public officers, and for politicians and public officers to learn to serve the public with sincerity. Laws should be tightened ${ }^{88}$ so that such public institutions may not only ensure the removal from office of an elected leader or appointed office holder, but also see to it that the removal does not serve the interest of the one removed (from office) other than serving that of the state. This, for instance, may not be achieved if the one removed from office is not made, in addition, to refund any stolen money - or, generally, lose money or assets equivalent to the value of the harm which she has caused to the state.

The above discussion on political corruption is relevant to our understanding of political morality within a moderate communitarian context. Contrary to Gyekye, I do not think that moral revolution will be preferred to law enforcement in combatting political corruption in the Akan community. Although for an individual to engage in corruption, she would have indeed engaged in an immoral act, technically a chief or anyone who becomes a member of the traditional council of elders would normally be someone seen to have good moral character and interested in the well-being of her clan and community. The people's demand, as noted above, that such individuals be at the helm implies already that the latter are expected to commit to the known communitarian values, especially morality. However, since the Akan community is aware of the impracticality of having the same levels of commitment from all public officers, Gyekye's request that they all commit fully to moral values in order to eliminate political corruption amounts to a restatement of the ideal standard (which the community anticipates that some public officers may miss anyway). It is thought, rather, that since political corruption and other immoral acts are deliberate and ultimately harm the individual in whom moderate communitarianism is interested, the individual ought to be empowered by law to safeguard her interest. This is the basis for the customary law that requires community members to depose bad chiefs including those whose corrupt acts are influenced by the idea of 'selling an old lady'.

I have already stated that law enforcement on corruption has a moral identity and this can be seen in the Akan communitarian society as well. In the case of the individual, her failure to support the deposition of an immoral chief, for instance, could be considered immoral since her (non)action will indirectly allow the actual or potential perpetuation of immorality by that chief. Also, if traditional political leaders fail to apply the law in a fair way on individuals who commit economic crimes, for instance, it would be immoral as well. Moderate communitarianism therefore sees political corruption as a moral problem but it attempts to deal with it practically and effectively through law enforcement.

\footnotetext{
${ }^{88}$ In Ghana, the extreme need for this is shown annually when the Auditor General's Annual Report reveals acts and perpetrators of corruption in the public sector, and the culprits are only brought before a Parliamentary Committee. This Committee interrogates the officials live on national TV in order to seek an explanation, embarrass those who are unable to account to them, and very often, that is it. The public hears nothing more of what happens next to these officials - if indeed something ever happens. But, while this public embarrassment helps, it is really not enough. On $19^{\text {th }} \mathrm{July}, 2017$ Ghana's Parliament passed the Office of the Special Prosecutor bill giving the mandate to the Office to prosecute such corrupt public officers as those that will be cited in the Auditor General's Report. However, the Office has not yet started prosecutions as of today 31 July, 2018.
} 


\section{Conclusion}

From the foregoing, it may be observed that ensuring good political morality within a democratic framework calls for commitment on the part of politicians and public officials to the tenets of democratic leadership which, ultimately, amounts to respect for the rights and dignity of all citizens, and the promotion of their general well-being. Since these are democratic goods which are best achieved at the state level, working toward their realisation constitutes political morality. It may also be observed that although there are many challenges that make it difficult for these to be achieved in African democratic practice, how best moderate communitarianism helps to address two of those challenges - viz. human rights and political corruption - has been explained. Since moderate communitarianism does not neglect the rights of the individual, and its criteria of personhood and strict accountability help in dealing with corruption, moderate communitarianism could indeed be a useful tool in Africa's quest to improve her democratic practice. Moderate communitarianism is also put forward as a concept that makes it possible for political leaders, especially, to be moral and true to their roles in the Akan society. As such, this concept is offered as a viable model for ensuring good political morality - a virtue which contemporary African countries, given how they have fared so far in the areas of human rights and corruption, badly need in their practice of multi-party democracy. Toward the control of political corruption, therefore, Gyekye's preference for moral revolution to law enforcement has been shown to be conceptually and practically problematic. I have argued that law enforcement is a better solution to the problem of political corruption.

\section{References}

Ajei M.O. (2014), The Paranormal: An Inquiry into some Features of African Metaphysics and Epistemology, Missionshilfe Verlag, Hamburg.

Ajei M.O. (2015), “Human Rights in a Moderate Communitarian Political Framework," South African Journal of Philosophy 34 (4): 491-503.

Ake C. (1987), "The African Context of Human Rights," Africa Today 34 (1/2): 5-12.

Ani E.I. (2013), "Africa and the Prospects of Deliberative Democracy," South African Journal of Philosophy 32 (3): 207-219.

Coady C.A.J. (1993), "Politics and the Problem of Dirty Hands," [in:] A Companion to Ethics, P. Singer (ed), Blackwell Publishers, Oxford: 373-383.

Cobbah A.A.J. (1987), "African Values and the Human Rights Debate: An African Perspective," Human Rights Quarterly 9 (3): 309-331.

Dworkin R.M. (1975), “Hard Cases," Harvard Law Review 88 (6): 1057-1109.

Dzobo N.K. (1992), "The Image of Man in Africa," [in:] Person and Community: Ghanaian Philosophical Studies, I.K. Wiredu, K. Gyekye (eds), The Council for Research in Values and Philosophy, Washington DC: 123-135.

Famakinwa J.O. (2010), "How Moderate is Kwame Gyekye's Moderate Communitarianism?" Thought and Practice: A Journal of the Philosophical Association of Kenya 2 (2): 65-77.

Gyekye K. (1992), "Person and Community in Akan Thought," [in:] Person and Community: Ghanaian Philosophical Studies, I.K. Wiredu and K. Gyekye (eds), The Council for Research in Values and Philosophy, Washington DC: 101-122. 
Gyekye K. (1995), An Essay on African Philosophical Thought: The Akan Conceptual Scheme, Temple University Press, Philadelphia.

Gyekye K. (1996), African Cultural Values, Sankofa Publishing, Accra.

Gyekye K. (1997), Tradition and Modernity: Philosophical Reflections on the African Experience, Oxford University Press, Oxford.

Gyekye K. (2004), The Unexamined Life: Philosophy and the African Experience, Legon Sankofa Publishing.

Halberstam D. (2004), “The Political Morality of Federal Systems,” Virginia Law Review 90 (3): 731-834.

Machiavelli N. (1984), The Prince, trans. P. Bondanella and M. Musa, Oxford University Press, Oxford.

Machiavelli N. (1950), The Discourses, trans. L.J Walker, Penguin, Harmondsworth.

Majeed H.M. (2013), "A Critique of the Concept of Quasi-Physicalism in Akan Philosophy," African Studies Quarterly 14 (1-2): 23-33.

Majeed H.M. (2018), "Moderate Communitarianism is Different: A Response to J.O. Famakinwa and B. Matolino," Journal of Philosophy and Culture 6 (1): 3-15.

Matolino B. (2009), "Radicals versus Moderates: A Critique of Gyekye's Moderate Communitarianism," South African Journal of Philosophy 28 (2): 160-170.

Matolino B. (2011), “The (Mal)Function of 'It'in Ifeanyi Menkiti's Normative Account of Person," African Studies Quarterly 12 (4): 23-37.

Matolino B. (2014), Personhood in African Philosophy, Cluster Publications, Dorpspruit.

Mbiti J.S. (1989), African Religions and Philosophy, Heinemann, New Hampshire.

Menkiti I.A. (1984), "Person and Community in African Traditional Thought," [in:] African Philosophy: An Introduction, R.A. Wright (ed), University Press of America, Lanham: 171-181.

Mubiala M.M. (2010), “The Contribution of African Human Rights Traditions and Norms to United Nations Human Rights Law," Human Rights and International Legal Discourse 4 (2): 210-240.

Nielsen K. (2000), "There is no Dilemma of Dirty Hands," [in:] Cruelty and Deception: The Controversy over Dirty Hands in Politics, D.P. Shugarman and P. Rynard (eds), Broadview Press, Peterborough, Ontario: 139-155.

Ramose M. (2001), "An African Perspective on Justice and Race," (A web publication by Polylog: Forum for Intercultural Philosophy), URL = http://them.polylog.org/3/ frm-en.htm. [Accessed: 20.1. 2014].

Raz J. (1994), Ethics in the Public Domain: Essays in the Morality of Law and Politics, Clarendon Press, Oxford.

Rawls J. (1999), The Law of Peoples, Harvard University Press, Cambridge MA.

Shivji G.I. (1989), The Concept of Human Rights in Africa, Codesria Book Series, London.

Silk J. (1990), "Traditional Culture and the Prospect of Human Rights in Africa," [in:] Human Rights in Africa: Cross Cultural Perspectives, A.A. An-Na'im and M.F. Deng (eds), The Brookings Institution, Washington DC.

Tempels P. (1979), Bantu Philosophy, Presence Africaine, Paris.

Wiredu K. (1983), "The Akan Concept of Mind," Ibadan Journal of Humanistic Studies 3: 113-134.

Wiredu K. (1990), "An Akan Perspective on Human Rights," [in:] Human Rights in Africa: Cross Cultural Perspectives, A.A. An-Na'im and M.F. Deng (eds), The Brookings Institution, Washington DC: 243-260.

Wiredu K. (1996), Cultural Universals and Particulars, Indiana University Press, Indianapolis. 